\title{
Techno-Economic Evaluation and Optimization of Grid Connected PV and Wind Generating System for Riyadh City
}

\author{
Fahd A. Alturki, Abdulhakim Bin Dayil \\ Electrical Engineering Department, King Saud University, Riyadh, Saudi Arabia \\ Email: falturki@ksu.edu.sa,439105812@student.ksu.edu.sa
}

How to cite this paper: Alturki, F.A. and Dayil, A.B. (2020) Techno-Economic Evaluation and Optimization of Grid Connected PV and Wind Generating System for Riyadh City. Journal of Power and Energy Engineering, 8, 46-63.

https://doi.org/10.4236/jpee.2020.812004

Received: December 5, 2020

Accepted: December 27, 2020

Published: December 30, 2020

Copyright $\odot 2020$ by author(s) and Scientific Research Publishing Inc. This work is licensed under the Creative Commons Attribution International License (CC BY 4.0).

http://creativecommons.org/licenses/by/4.0/

\begin{abstract}
The risks and challenges faced by human society at the moment are global warming, climate change and pollution. In addition to their effect on the atmosphere, the quantity of fossil fuels is beginning to decrease, and countries have taken steps to encourage greater use of renewable energy resources. This article explores the feasibility of supplying electricity from a hybrid power system (HPS) comprising wind/photovoltaic (PV) and batteries. Taking into account residential buildings that consume the largest portion of energy in Saudi grid, Saudi Arabia, Riyadh is the preferred city with distinctive geographical and climatic conditions. The hourly electricity demand data must be over 8760 hours during a 1-year analysis in order to assess the optimum design and operational planning of the HPS. The economic analysis is carried out by applying HOMER software on the basis of net present cost (NPC), energy cost (COE) and the renewable fraction for all situations. In addition, to specify the effect of fuel costs on the scheme, sensitivity tests are carried out by considering two separate tariff rates for residential consumers. The results of the economic analysis show that current tariff is not economic to use HSP under warm and temperate climate conditions compare to using electricity from grid and the expected forecasted tariff shows it's economic to use HSP compare to grid electricity.
\end{abstract}

\section{Keywords}

Solar, Grid, Optimization, Cost, HOMER Pro ${ }^{\circledR}$ Software

\section{Introduction}

The energy demand has increased due to population growth. As a result, meeting energy requirements is a growing concern for governors. Under such cir- 
cumstances, finding an alternative, clean, and low-cost source of energy is of the utmost importance. Limited reserves of fossil fuels, sustainability enhancement, diversification of energy supplies and environmental impacts of fossil fuels have led to increased utilization of renewable energies.

Moreover, the renewable technologies provide a sustainable and cost-effective alternative for fighting carbon pollution. Consequently, the significant advancement in the global clean energy sector stems from renewable energy sources and they are one of the fastest-growing industries [1]. Given the fact that global energy consumption has been growing rapidly, it is predicted that the electricity generated from renewable energy sources will surpass natural gases and nuclear power, and renewables will become dominant in energy production by the end of 2040. The strategic energy planning process is a framework that can be modified to meet each community's need. World energy consumption is increasing substantially, according to International Energy Agency the world energy consumption in 2018 is 25,721 TWh where almost $60 \%$ of the produced energy around the world emits carbon dioxide $\left(\mathrm{CO}_{2}\right)$. We can calculate the contribution of the average citizen of each country by dividing its total emissions by its population. This gives us $\mathrm{CO}_{2}$ emissions per capita [1].

Saudi Arabia has a growing economy. The energy consumption per capita is increased throughout the country with a substantial percentage. The reason of significant energy consumption is the decline in the exports of fossil fuels. The previous decade experienced much energy consumption equivalent to more than 500 million barrels of oil. It is expected that the total consumption of energy could be double in 2030. Evidently, as per given data of Saudi Electric Company, the total share of hydrocarbon i.e. oil is $63 \%$ and gas is $37 \%$. The data further integrated and demonstrated that the in 2008 the total hydrocarbon consumption is 1766 TWh to fulfill the energy needs of different sectors. The growth of primary energy demand from 2004-2008 is 1366 TWh, and with the current consumption ratio in 2020 (2035 TWh), it will increase up to $2593 \mathrm{TWh}$ in 2030. It will lead to further decline in the fossil fuel [2].

The world's largest per capita $\mathrm{CO}_{2}$ emitters are the major oil producing countries; this is particularly true for those with relatively low population size. Most are in the Middle East: In 2017 Qatar had the highest emissions at 49 tonnes $(\mathrm{t})$ per person, followed by Trinidad and Tobago (30t); Kuwait (25t); United Arab Emirates (25t); Brunei (24t); Bahrain (23t) and Saudi Arabia (19t). Figure 1 shows carbon dioxide per person in year for Saudi Arabia. In the visualization we see the differences in per capita emissions across the world [3].

Various research work has been done on modeling hybrid systems that can generate much less emissions and can eventually replace the traditional way of producing electricity.

An off-grid solar-wind hybrid system is proposed for a university campus in Pakistan that will operate during power supply unavailability or shedding scenario. The University campus model has very low energy (COE) and Net Present 


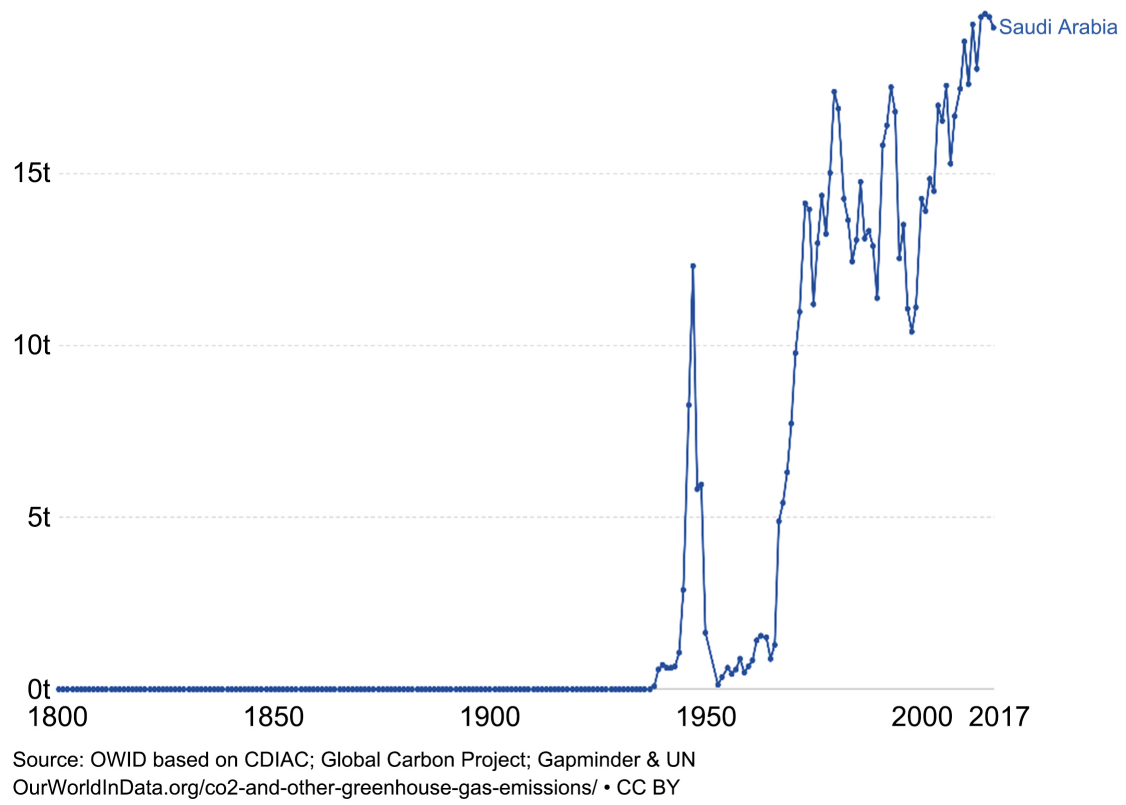

Figure 1. $\mathrm{CO}_{2}$ emissions per capita (Source: our world in data [3]).

Cost (NPC) costs [4]. Hybrid energy system focused on PV-generator batteries for Aha Village, Morotai Island, North Maluku. Here, the authors considered two forms of loads for the village, i.e. communal and administrative. The results of the optimization show that both types of load can be easily satisfied by the proposed hybrid model [5]. Off-grid PV-wind battery hybrid system for three regions of Morocco that easily meets the load of those areas. The result also shows that the hybrid method can only be used if significant resources are available [6].

Study shows that among the cities considered in the study, Kish Island has mild and temperate climate, highest solar radiation and the lowest value for $\mathrm{COE}$ is the most economically and environmentally feasible city to meet the energy needs of all three types buildings. In addition to the substantial decrease in diesel fuel consumption, emission of $\mathrm{CO}_{2}, \mathrm{NPC}$ and $\mathrm{COE}$ prices, this shows that renewable energy is more environmentally friendly and cost-effective than traditional energy sources [7].

\section{Overview of the Electricity Sector in Saudi Arabia}

Electricity generation capacity in 2018 reach $85.556 \mathrm{GW}$ with 79 power plant of different producers, in between 2013-2018 around 49.4 GW have been added to the power system likely, due to increased consumption and higher energy demand in the kingdom. Based on International Energy Agency, Saudi Arabia generate electricity by using oil and gas on steam turbines (41\%), gas turbines (41), diesel generator (1\%) and combined cycle unite (17\%) as it mentioned below (Figure 2). 


\section{Energy consumption by source, Saudi Arabia}

Energy consumption is measured in terawatt-hours (TWh). Here an inefficiency factor has been applied for fossil

fuels. meaning the shares by each energy source give a better approximation of final energy consumption.

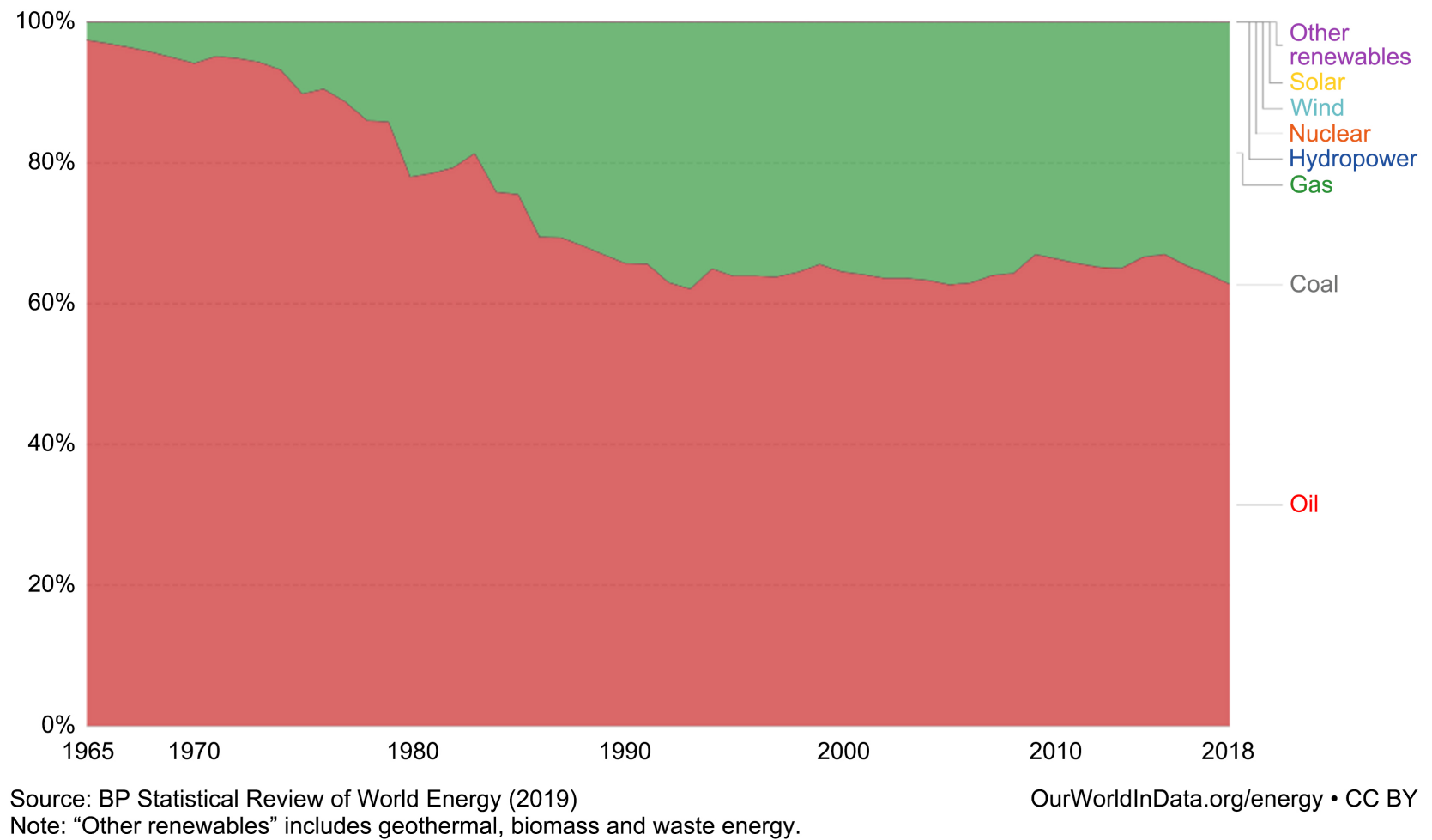

Note: "Other renewables" includes geothermal, biomass and waste energy.

Figure 2. Energy consumption by source in Saudi Arabia (Source: our world in data [3]).

Integration of power sources in power system has the upside of decreasing greenhouse gas emanation, henceforth helping with settling an unnatural global warming issue. It additionally helps decline our reliance on non-renewable energy source in power areas. Accordingly, renewable energy resources are viewed as a piece of the answer for alleviate ecological issues brought about by the utilization of traditional vitality assets. Right now, assets offer clean energy generations, permitting the charge of no-associated and remote zones, add to diminish reliance on non-renewable energy sources. They additionally have improved their innovations and diminished expenses. Nevertheless, the capital expense of sustainable force plant is exceptionally high contrasted with conventional power sources. However, the operating cost is less expensive than the one for conventional source and will keep on declining with modern technical improvement [8].

Since the greater part of sustainable resources are discontinuous in nature, it is invaluable to use more than one asset when accessible. Hybridizing of inexhaustible assets improves the energy system reliability, proficiency and economy, particularly in places with great attributes of sun and wind.

\section{Renewable Energy in Energy Portfolio}

The geographic location of KSA is well placed for capitalizing solar energy with 
the average daily solar radiation level between $5.69-6.62 \mathrm{kWh} / \mathrm{m}^{2}$ and $80 \%$ $90 \%$ of clear sky days over the year as shown in Figure 3 [9] [10]. High availability of neutral sources like solar and wind guide the world trending to use renewable energy and identify valuable opportunities to further reduce future energy costs and $\mathrm{CO}_{2}$. Hence, according to Vision 2030, Saudi Arabia aims to boost its renewable energy resources in its total energy share by producing nearly $9.5 \mathrm{GW}$ of energy from sustainable energy sources by 2023, of which solar photovoltaic (PV) generation comprises a considerable portion [9].

In addition to the solar over the kingdom, It shows that minimum and maximum wind speed over the Saudi Arabia $6 \mathrm{~m} / \mathrm{s}$ and $10 \mathrm{~m} / \mathrm{s}$ repetitively as shown in Figure 4.

SOLAR RESOURCE MAP

GLOBAL HORIZONTAL IRRADIATION SAUDI ARABIA

WORLD BANK GROUP

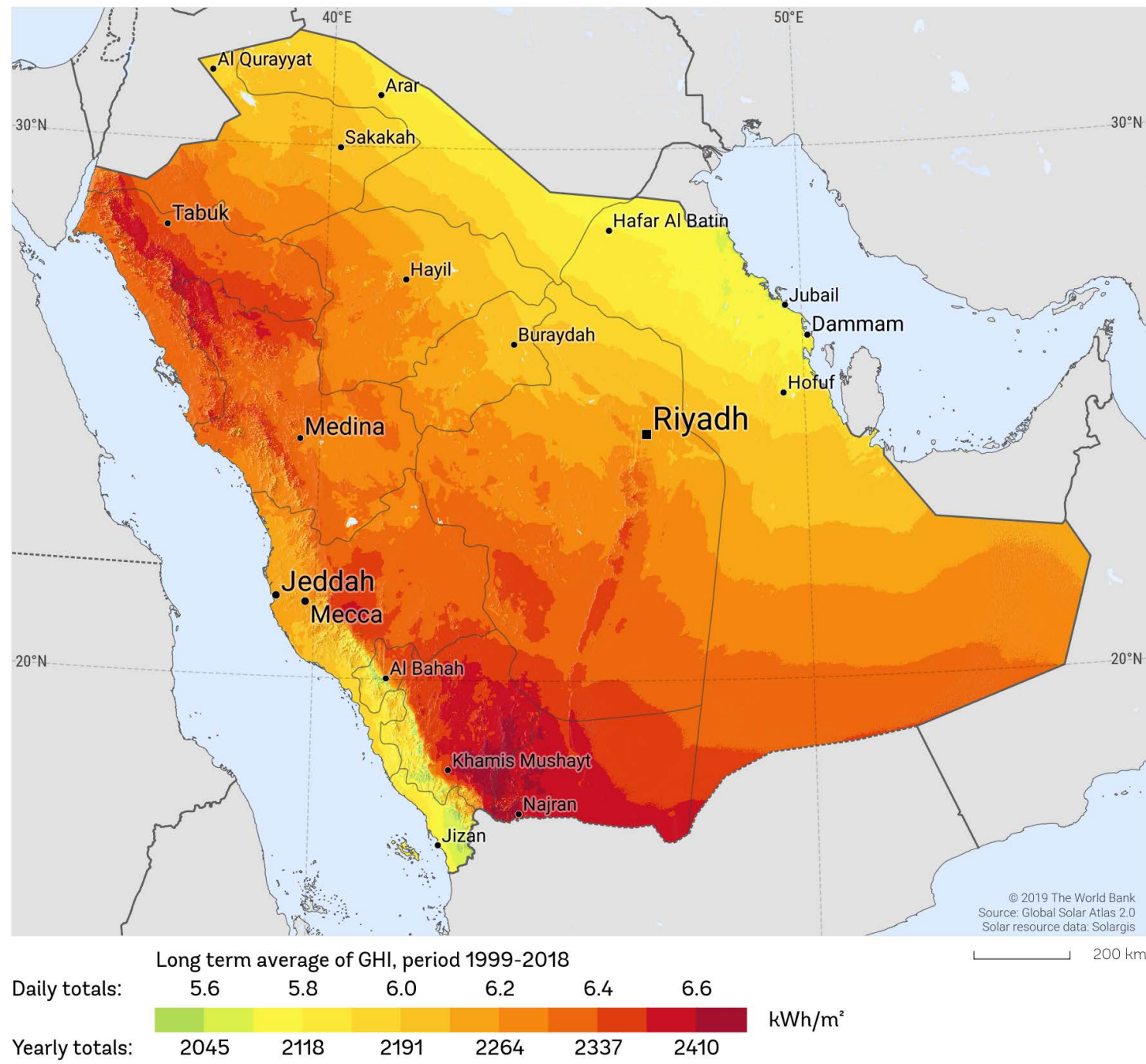

This map is published by the World Bank Group, funded by ESMAP. and prepared by Solargis, For more information and terms of use, please visit http://globalsolaratlas.info

Figure 3. Global horizontal irradiation overt the kingdom (source: Global Solar Atlas [10]). 


\section{Potential Renewable Energy Systems in Chosen Location in Different Areas in KSA}

Kingdom of Saudi Arabia is an Arab country and it is the largest nation in the Middle Orient and it is primarily situated in the southwest of the continent of Asia and forms the largest region of the Arab Peninsula with a latitude and length of approximately two million square $\mathrm{km}\left(23^{\circ} 43^{\prime} 00^{\prime \prime} \mathrm{N} 44^{\circ} 07^{\prime} 00^{\prime \prime} \mathrm{E}\right)$, respectively, and it has a diverse climate and a particular topographic character in this analysis. Riyadh city has been considered. The location Riyadh in Saudi Arabia is shown in Figure 5.

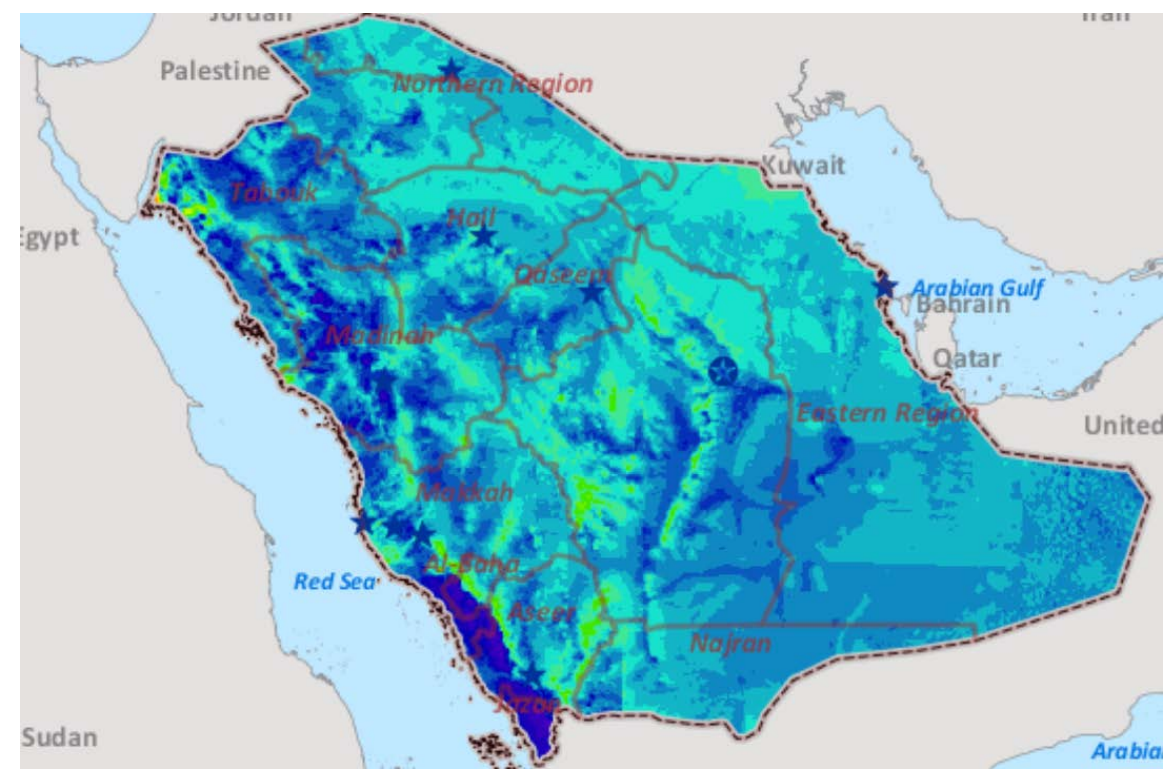

Figure 4. Yearly average wind speed overt the kingdom (source: K.A.CARE [11]).

\section{SAUDI ARABIA}

Enter your sub headline here

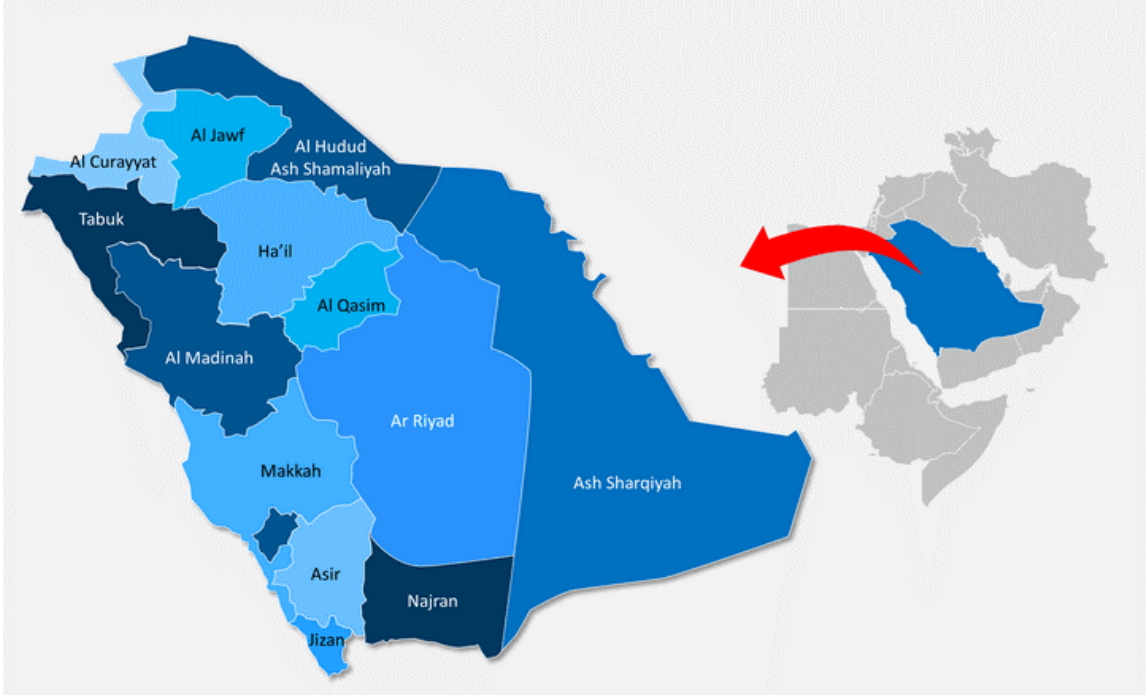

Figure 5. Riyadh city location. 


\section{Site Characterization}

\subsection{System Design}

Mathematical model: PV [12]

$$
\mathrm{P}_{\mathrm{PVA}}=\mathrm{N}_{\mathrm{PV}} \mathrm{V}_{\mathrm{PV}} \mathrm{I}_{\mathrm{PV}}
$$

Mathematical model: Wind Turbine

Two or more binomial expressions are used to ensure fitting accuracy. The fitting equation of the wind generator output characteristic can be expressed as [12]:

$$
P_{W G}(V)= \begin{cases}0 & \text { for } V<V_{c i} \\ a_{1} V^{5} \cdots b_{1} V^{2}+c_{1} V+d_{2} & \text { for } V_{c} \leq V_{c}<V_{1} \\ a_{2} V^{5} \cdots b_{2} V^{2}+c_{2} V+d_{2} & \text { for } V_{1} \leq V<V_{2} \\ a_{3} V^{5} \cdots b_{3} V^{2}+c_{3} V+d_{3} & \text { for } V_{2} \leq V<V_{f} \\ 0 & \text { for } V>V_{c o}\end{cases}
$$

(V) is wind speed at the hub height.

$\left(\mathrm{V}_{\mathrm{ci}}\right)$ is the cut-in wind speed.

$\left(\mathrm{V}_{\mathrm{Co}}\right)$ is the cut-off wind speed.

Mathematical model: Batteries.

Where the total output of PV and wind generators is larger than the demand for load during the charging period, the available battery bank capacity can be represented by [12]:

$$
\mathrm{C}_{\text {Bat }}(\mathrm{t})=\mathrm{C}_{\text {Bat }}(\mathrm{t}-1) \times(1-\sigma)+\left(\mathrm{E}_{\mathrm{PV}}(\mathrm{t})+\mathrm{E}_{\mathrm{WG}}(\mathrm{t})-\frac{\mathrm{E}_{\mathrm{L}}(\mathrm{t})}{\eta_{\text {inv }}}\right) \eta_{\text {Bat }}
$$

where:

$\mathrm{C}_{\mathrm{Bat}}(\mathrm{t})$ and $\mathrm{C}_{\mathrm{Bat}}(\mathrm{t}-1)$ are the charge quantities of battery bank at the time $(\mathrm{t})$ and $(\mathrm{t}-1)$.

$\mathrm{E}_{\mathrm{PV}}(\mathrm{t})$ is the total energy generated by $\mathrm{PV}$ array.

$\mathrm{E}_{\mathrm{WG}}(\mathrm{t})$ is the total energy generated by wind Turbine.

$\mathrm{E}_{\mathrm{L}}(\mathrm{t})$ is load demand at the time $(\mathrm{t})$.

$(\sigma)$ is hourly self-discharge rate of the battery bank.

Mathematical model: System Performance.

As the lowest energy cost of these projects is more concerned, an economic model for the hybrid PV/ ind power generation system based on a leveled energy cost (COE) concept is developed [12].

$$
\mathrm{COE}=\frac{\mathrm{TPV}+\mathrm{CRF}}{\mathrm{E}_{\text {load }}}
$$

(CRF) is the cumulative present value of the actual cost of all components of the system including the replacement cost of hybrid system components as mentioned below [12].

$$
\mathrm{TRF}=\mathrm{C}_{\mathrm{PV}}+\mathrm{C}_{\text {Batt }}+\mathrm{C}_{\text {wind }}+\mathrm{C}_{\text {grid }}
$$




\subsection{System Schematic}

Figures 6-8 display the schematic configuration of the photovoltaic/wind/battery hybrid system for this analysis. As the demand for load is not constantly the same as solar panel and wind turbine power, battery banks are used to store energy in excess and then to use it when more energy is required. Moreover, any device that includes both AC and DC elements needs a converter to produce enough electricity.

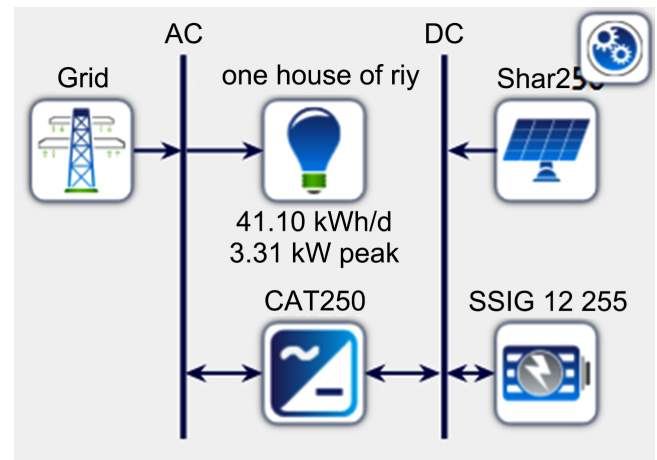

Figure 6. Schematic of PV-Battery.

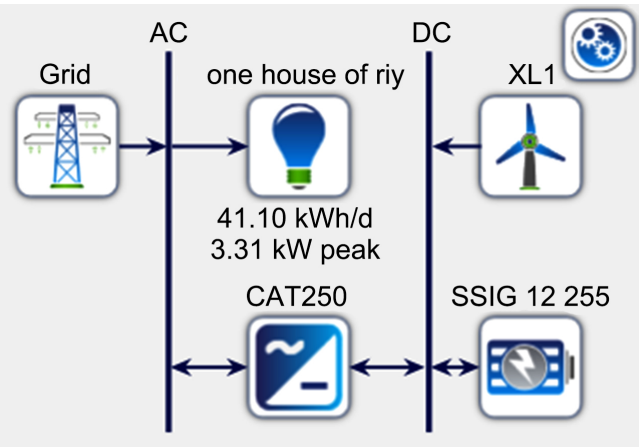

Figure 7. Schematic of Wind-Battery.

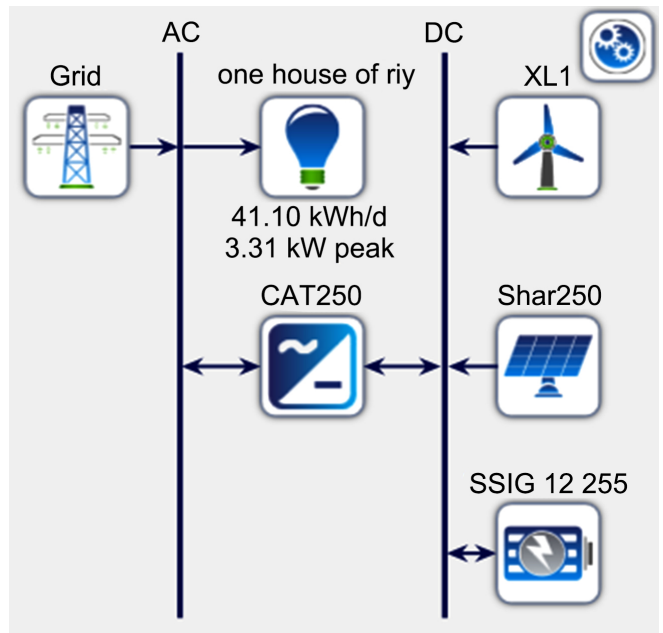

Figure 8. Schematic of PV-Wind-Battery. 
System \# 1: PV-Battery Generation system

System \#2: Wind-Battery Generation system

System \#3: PV-Wind-Battery Generation system

Components technical and economic specification:

The emissions g/kWh consider in Saudi Arabia about 929.85 where this is the carbon gram per kilo watt hour for Petroleum according to U.S. electric utility and independent power electricity generation and resulting $\mathrm{CO}_{2}$ emissions by fuel in 2018 [13].

\subsection{Load Profile Assessment}

This hybrid system has been planned to meet Riyadh City's energy needs for a residential load. The current demand for residential power in urban areas is strong, because of air conditioning. Energy use is strong in residential communities. In the current case the main energy consumption is due to the Ac units. Electric load evaluation was conducted carefully considering household load requirements for the summer peak season for residential requirements. The residential load estimates are mentioned in Table 1 . The load profile of the residential community's monthly average electricity consumption is shown in the Figure 9, with highest consumption of electricity between May and Oct. The AC units run and the warm temperature in the city of Riyadh.

Table 1. Monthly load profile of typical consumer in Riyadh City.

\begin{tabular}{|c|c|}
\hline Month & Consumption kWh \\
\hline Jan & 587.0 \\
\hline Feb & 596.6 \\
\hline Mar & 573.3 \\
\hline Apr & 1072.3 \\
\hline May & 1663.9 \\
\hline Jun & 1727.9 \\
\hline Jul & 1980.6 \\
\hline Aug & 1916.3 \\
\hline Sep & 1544.7 \\
\hline Oct & 1583.6 \\
\hline Nov & 1147.8 \\
\hline Dec & 606.1 \\
\hline Total & 15,000 \\
\hline
\end{tabular}




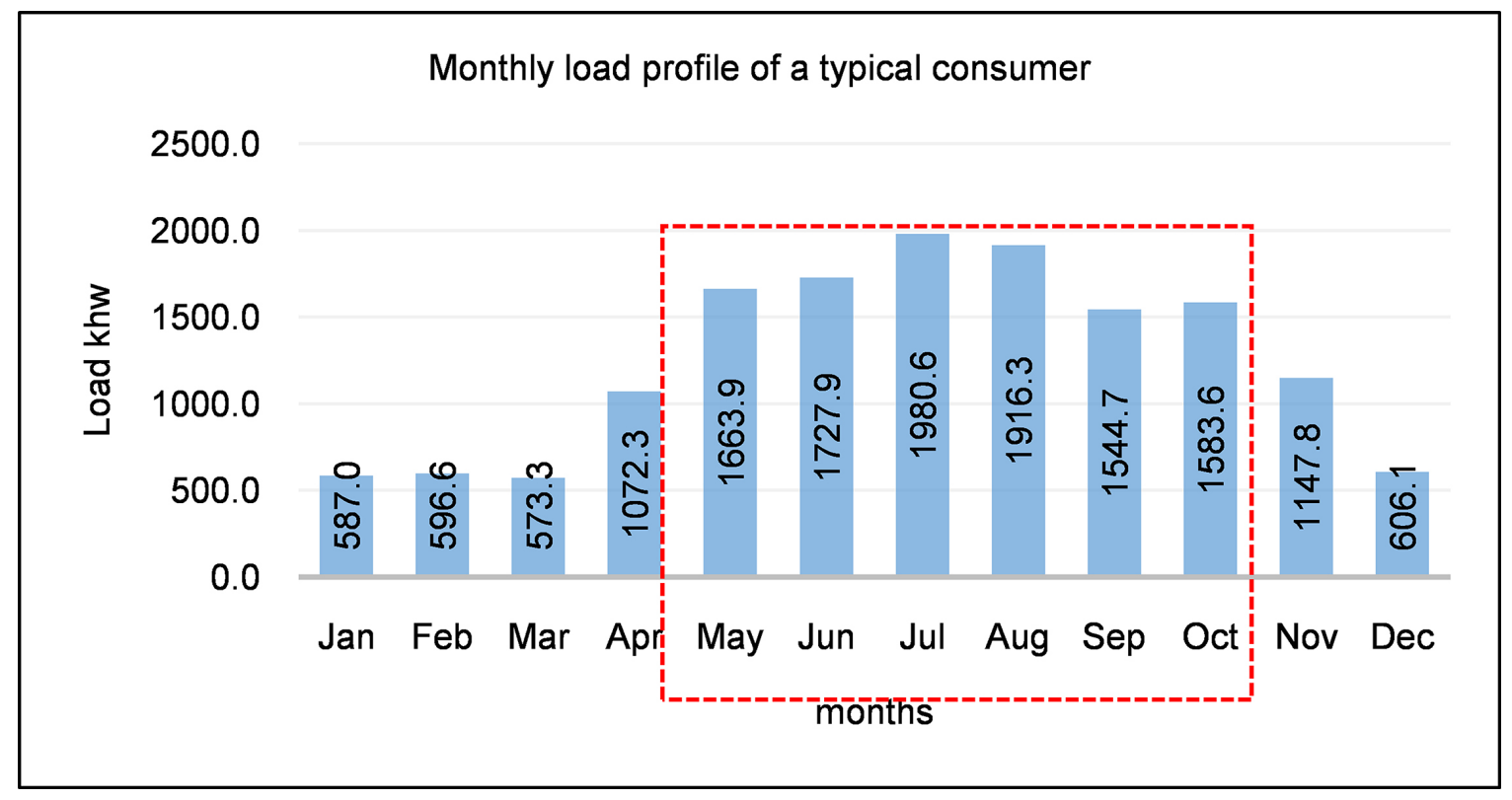

Figure 9. Monthly load profile of a typical consumer Riyadh city kWh.

\subsection{Available Resources Assessment}

In the present case, the hybrid solar/wind power system was taken into account. Therefore, the full assessment of the wind and solar resources available is given below:

\subsubsection{Available Solar Radiation Data}

Solar radiation data obtained by using HOMER software for the locations of Riyadh city from "Atlas website by K.A.CARE" Figure 10 [11]. The maximum solar radiations were found to be $6.95 \mathrm{kWh} / \mathrm{m}^{2} /$ day. Data shows that the location has good solar potential and can produce power in efficient way using photovoltaic (PV) panels. Below sampled of one day of a year in MAY. Using measured Global horizontal irradiation form Al-Uyaynah Research Station $24^{\circ} 54^{\prime} 36.0^{\prime \prime} \mathrm{N}$ $46^{\circ} 24^{\prime} 36.0^{\prime \prime} \mathrm{E}$ which considered the advanced solar measurement station in the world shown in Figure 11.

\subsubsection{Available Wind Speed Data}

Wind speed data obtained by using HOMER software for the location of Riyadh city from "Atlas website by K.A.CARE". Figure 12 [11] displays the monthly mean wind speed data, measured at $40 \mathrm{~m}$ above the ground level. The data have been obtained from the meteorological database for $3 \mathrm{yr}$ period of 2013-2016. The annual mean wind speed of is estimated to be $7.64 \mathrm{~m} / \mathrm{s}$ at $40 \mathrm{~m}$ height which demonstrates that the city benefits from the abundant wind resource. Using measured wind speed data City site station at Riyadh city $24^{\circ} 34^{\prime} 35.1^{\prime \prime} \mathrm{N} 46^{\circ} 21^{\prime} 10.0^{\prime \prime} \mathrm{E}$ which considered the advanced solar measurement station in the world Shown in Figure 13. 


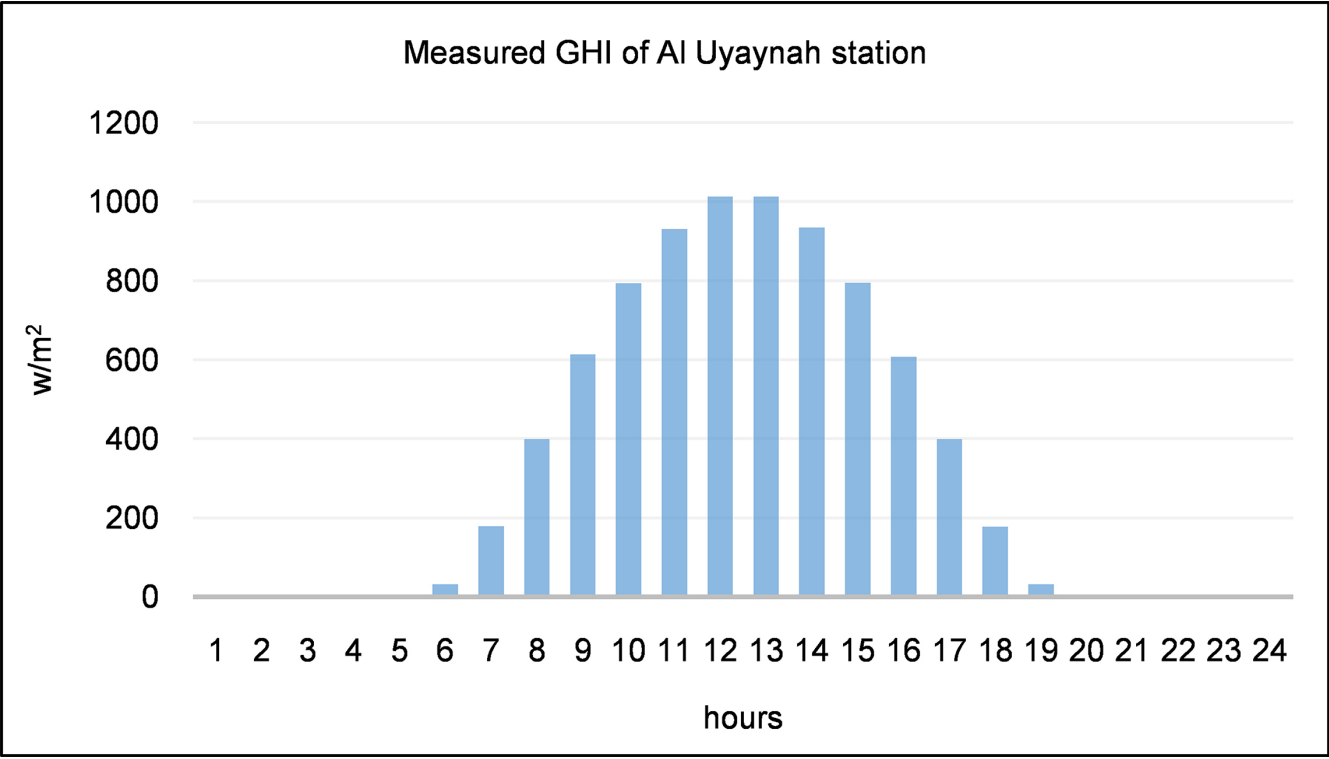

Figure 10. Global horizontal irradiation of Al Uyaynah station sample day in May [11].

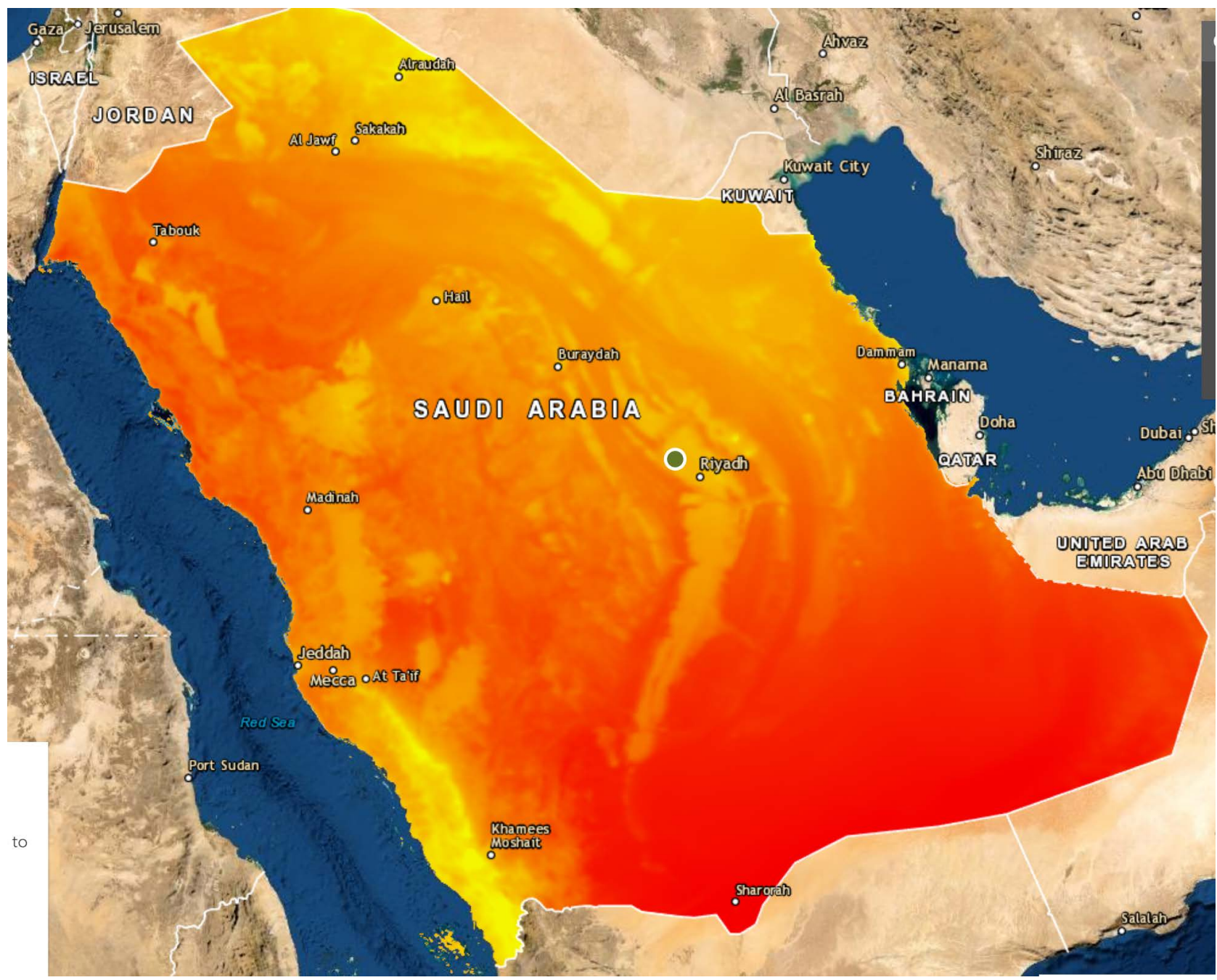

Figure 11. Al Uyaynah Research Measurement Station location in Saudi Arabia. 


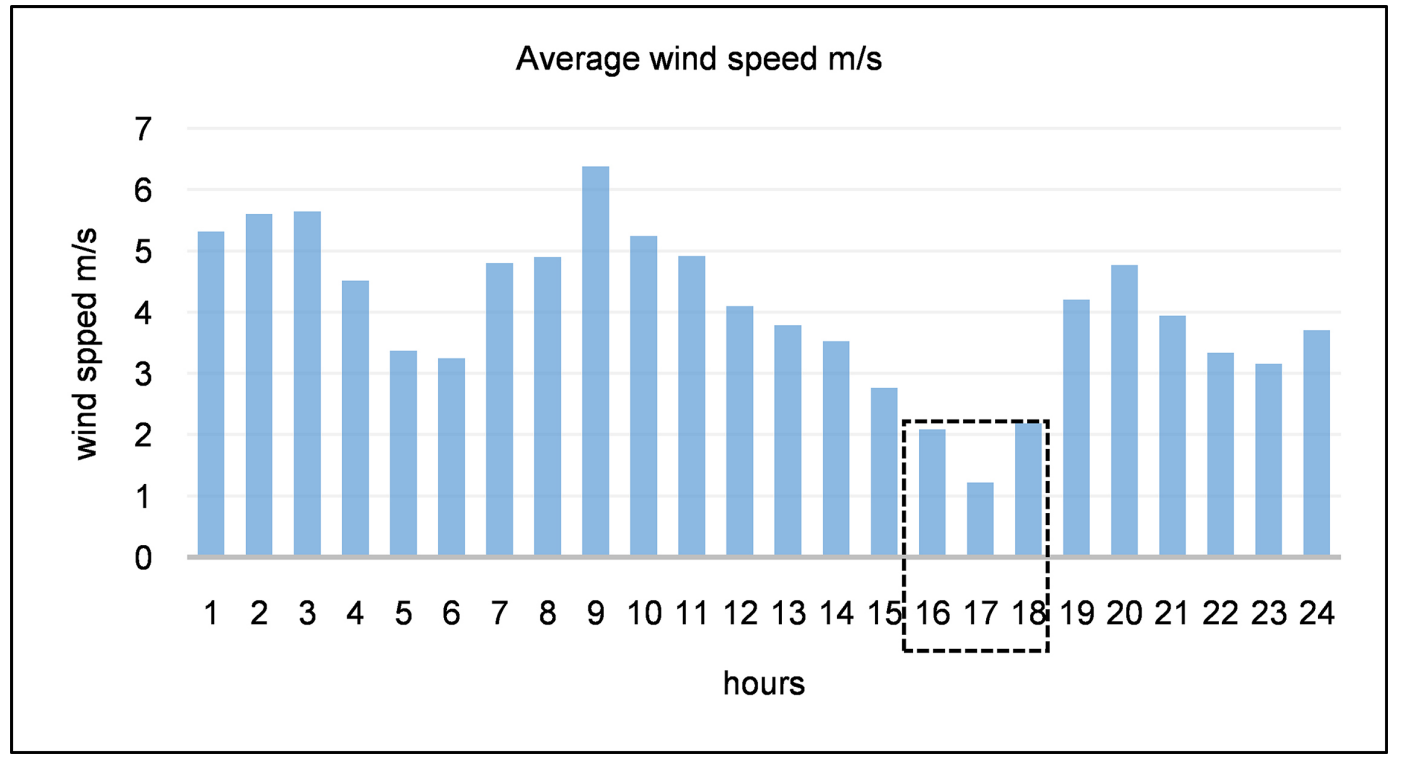

Figure 12. Average wind speed of city site station at Riyadh city Sample day of January [11].

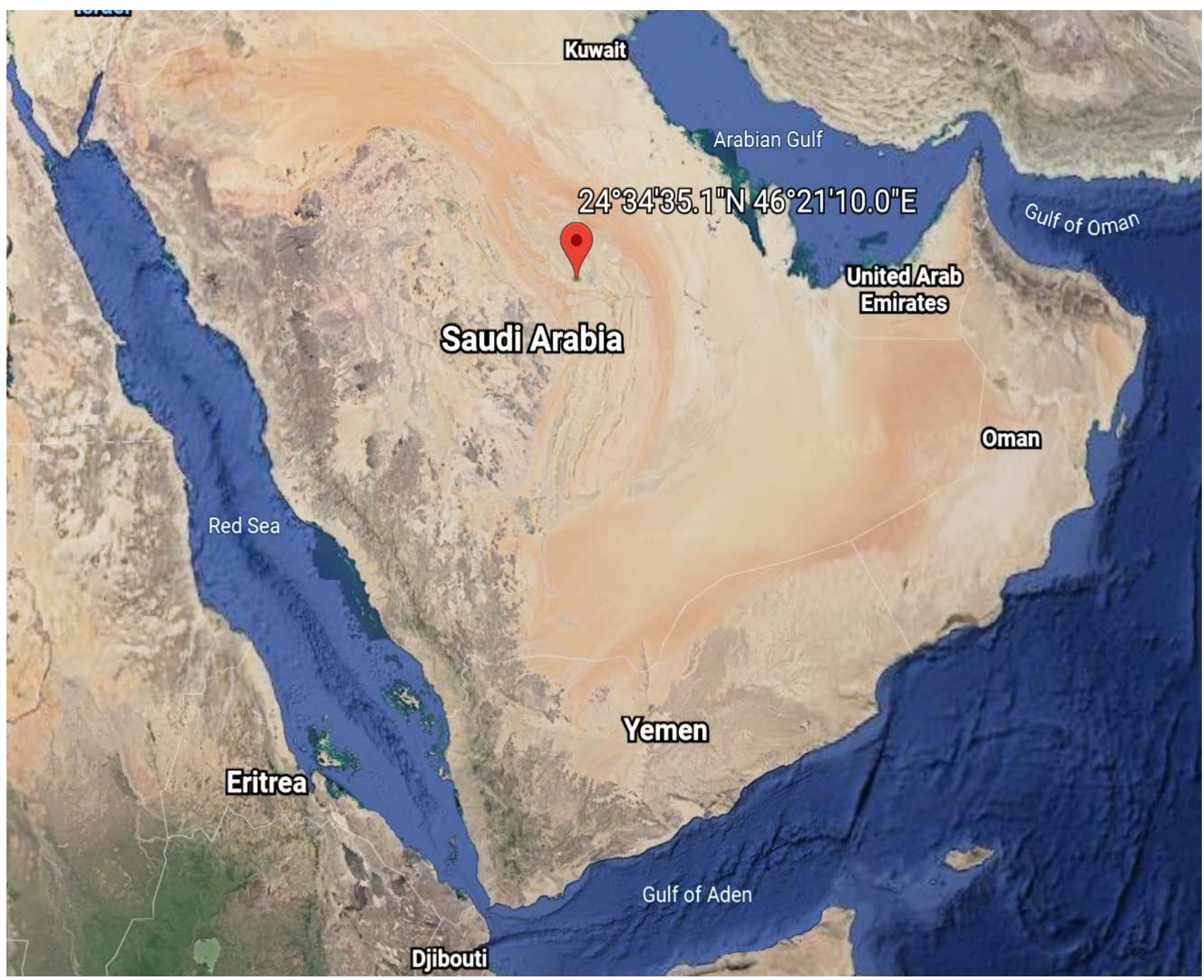

Figure 13. Wind Measurement Station location in Saudi Arabia [11]. 


\section{Methodology}

For optimal design and evaluation of the techno-economic feasibility of hybrid systems, HOMER software Pro 3.14.3 produced by NREL (National Renewable Energy Laboratory, USA) has been employed. This software is a powerful tool for the optimum design, scale and planning of renewable hybrid energy systems through technical and economic analysis of off-grid and on-grid power systems. It requires inputs such as electrical or heating loads to simulate the system or hybrid part combinations based on various set-ups and generates optimized systems sorted in terms of COE and NPC methodology of optimization presented in Figure 14 [15]. Device architecture configurations are optimized by limiting the objective feature to the limitations. In this analysis, the objective function is $\mathrm{COE}$ which is the current device expense, except the amount of the revenue. Battery charging and unloading, power balance and other technological limitations are the limitations. By making energy balance for an hour, HOMER simulates the system configurations and takes the electric or thermal loads per hour that can be supplied to the system [14].

This study shows the effect on COE and NPC of renewable penetration and storage. As HOMER analyzes and optimizes the pre-feasibility of the micro-grid systems before implementation. Typically, three tasks can be done with HOMER: simulations, sensitivity analysis and the simulated machine optimization [13].

Loads, modules and grids are three primary types of equipment for hybrid renewable systems. The electric loads for this analysis include PV, generators, batteries and converters. Tables 2-5 define the characteristics of these components which are modeled on HOMER.

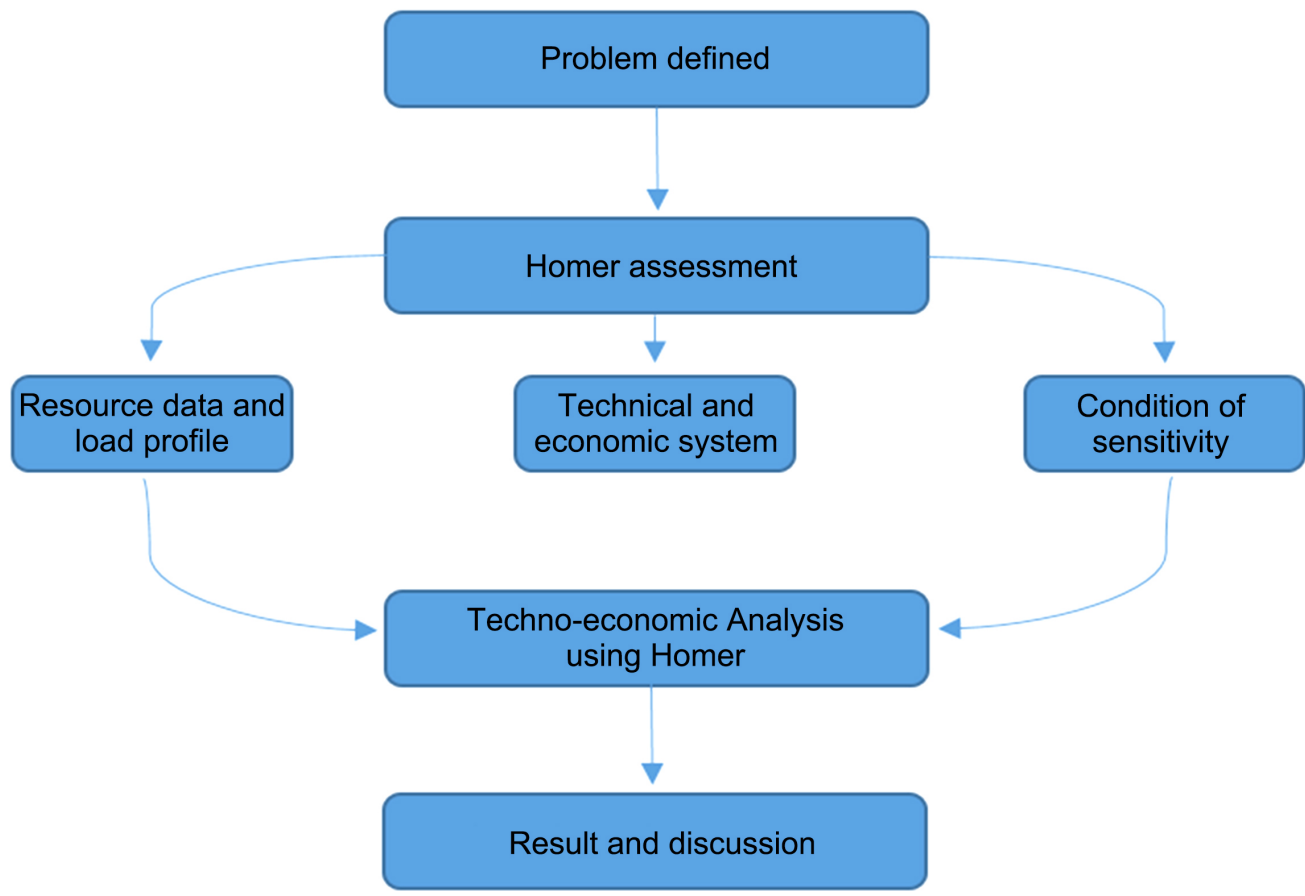

Figure 14. A schematic diagram indicating methodology utilized for analysis [15]. 
Table 2. Parameters of the hybrid system components in Homer.

\begin{tabular}{cccccc}
\hline Component & Model & Life time & Initial cost & Replacement cost & Maintenance cost \\
\hline Grid & - & - & - & - & - \\
Battery Bank & SSIG 12255 & & $300 \$ /$ Battery & $300 \$ /$ Battery & $4.5 \$ /$ year \\
PV module & ND-250QCS & 25 & $850 \$ / \mathrm{kW}$ & $800 \$ / \mathrm{kW}$ & $80.5 \$ /$ year \\
Wind Turbine & BWC XL.1 & 20 & $1500 \$ /$ turbine & $1200 \$$ & $50 \$ /$ year \\
Power Converter & BDP250 & 25 & $900 \$ /$ Converter & $800 \$ /$ Converter & $0 \$ /$ year \\
\hline
\end{tabular}

Table 3. Technical data used by the HOMER software.

\begin{tabular}{cc}
\hline Efficiency & $96 \%$ \\
Wind turbine cut-in & $2.5 \mathrm{~m} / \mathrm{s}$ \\
Wind turbine cut-off & $12.5 \mathrm{~m} / \mathrm{s}$ \\
Project life time & 25 years \\
Grid Electricity price & 0.048 and $0.08 \$ / \mathrm{kWh}$ \\
\hline
\end{tabular}

Table 4. Technical Specifications of Bergey XL.1 - $1 \mathrm{~kW}$.

\begin{tabular}{cc}
\hline Start-up Wind Speed & $3 \mathrm{~m} / \mathrm{s}(6.7 \mathrm{mph})$ \\
Cut-in Wind Speed & $2.5 \mathrm{~m} / \mathrm{s}(5.6 \mathrm{mph})$ \\
Rated Wind Speed & $11 \mathrm{~m} / \mathrm{s}(24.6 \mathrm{mph})$ \\
Rated Power & $1000 \mathrm{watts}$ \\
Furling Wind Speed & $13 \mathrm{~m} / \mathrm{s}(29 \mathrm{mph})$ \\
Max. Design Wind Speed & $54 \mathrm{~m} / \mathrm{s}(120 \mathrm{mph}$ \\
Type & 3 Blade Upwind \\
Rotor Diameter & $2.5 \mathrm{~m}(8.2 \mathrm{ft})$. \\
Over speed Protection & AUTOFURL \\
\hline
\end{tabular}

Table 5. Technical Specifications of ND-250QCS $250 \mathrm{~W}$.

\begin{tabular}{cc}
\hline Maximum Power (Pmax) & $250 \mathrm{~W}$ \\
Tolerance of Pmax & $+5 \% /-0 \%$ \\
PTC Rating & $223.6 \mathrm{~W}$ \\
Type of Cell & Polycrystalline silicon \\
Cell Configuration & 60 in series \\
Open Circuit Voltage (Voc) & $38.3 \mathrm{~V}$ \\
Maximum Power Voltage (Vpm) & $29.8 \mathrm{~V}$ \\
Short Circuit Current (Isc) & $8.90 \mathrm{~A}$ \\
Maximum Power Current (Ipm) & $8.40 \mathrm{~A}$ \\
Module Efficiency (\%) & $15.3 \%$ \\
Maximum System (DC) Voltage & $600 \mathrm{~V}$ \\
Series Fuse Rating & $15 \mathrm{~A}$ \\
\hline
\end{tabular}




\section{Optimization Method}

The optimization of the system has been done according to the leveled cost of energy (COE) concepts and compare to SEC tariff prices for residential consumers (two tariff has been considered for the electricity coming from the grid) The terms "Total NPC" and "Total NPC" for all schemes, including the initial capital cost final price of operating costs in addition to $\mathrm{CO}_{2}$ emissions per system, for electricity tariff prices of US $\$ 0.08 / \mathrm{kWh}$ have been considered in Table 6 shows that the optimum configuration of the optimization of renewable energy was the lowest NPC and COE for PV-Grid system. The system does not need batteries due to the consumer's load behavior. using batteries would increase the capital cost of the system and increasing $\mathrm{COE}$ as it mentioned in the second system in Table 6 and is not the highest prices due to the price of PV-Battery system would be also less than the price of electricity grid where the electricity of the grid coming in the third table where first tire $1-6000 \mathrm{kWh}$ cost $0.048 \$ / \mathrm{kWh}$ and second tariff is $>6000 \mathrm{kWh}$ cost $0.08 \$ / \mathrm{kWh}$.

\section{Result}

Table 6, Table 7 shows the results of the simulations of the optimal systems for each case study and the economic assessments based on NPC and COE parameters. Sensitivity case studies in Saudi Arabia often take into account the current price of electricity in the residual categorization prices of $\$ 0.048 / \mathrm{kWh}$ and the potential projected prices of $\$ 0.08 / \mathrm{kWh}$. Systems in various configurations are tested. PV-Grid 2. PV-Battery-Grid 3. Wind-Grid 4. Wind-Battery-Grid 5. PVWind-Grid 6. PV-Wind-Battery-Grid. In Table 7 for the Total NPC and Total NPC, plus the initial expense of the operating cost, for both systems. In addition to the emission of $\mathrm{CO}_{2}$ per device, only the $0.048 \$ / \mathrm{kWh}$ tariff price of Table 7 is considered. Also, show optimum systems optimization. Table 7 shows that the use of renewables is not economical for a typical Riyadh user with an annual consumption of $15,000 \mathrm{kWh}$ per year, because of a COE scheme than electricity for the grid. so, it is obvious the grid coming as the economic NPC and COE as it shows in Table 7.

Table 6. Generalization of renewable energy systems optimization in riyadh for electricity tariff of $0.08 \$$.

\begin{tabular}{|c|c|c|c|c|c|c|c|c|c|}
\hline PV & WIND & Battery & Grid & NPC & $\mathrm{COE}$ & operating cost & $\begin{array}{c}\text { Cost/Initial } \\
\text { capital (\$) }\end{array}$ & $\begin{array}{c}\text { System/Ren } \\
\text { Frac (\%) }\end{array}$ & $\begin{array}{c}\text { emmsion } \\
\mathrm{kg} / \mathrm{yr}\end{array}$ \\
\hline 2.036 & & & on & 16215.990 & 0.075 & 963.832 & 2631.788 & 21.0768 & 7601 \\
\hline \multirow[t]{2}{*}{1.982} & & 1 & on & 16492.320 & 0.077 & 965.914 & 2878.783 & 20.70087 & 7631 \\
\hline & & & on & 16912.740 & 0.080 & 1200.000 & 0.000 & 0 & 9480 \\
\hline 1.963 & 1 & & on & 18113.440 & 0.084 & 995.881 & 4077.545 & 23.66246 & 7356 \\
\hline \multirow[t]{3}{*}{1.891} & 1 & 1 & on & 18389.850 & 0.086 & 998.934 & 4310.935 & 23.19167 & 7393 \\
\hline & 1 & & on & 18973.440 & 0.090 & 1232.888 & 1597.181 & 2.528687 & 9240 \\
\hline & 1 & 1 & on & 19233.290 & 0.091 & 1224.962 & 1968.750 & 3.053514 & 9191 \\
\hline
\end{tabular}


Table 7. Generalization of renewable energy systems optimization in riyadh for electricity tariff of $0.048 \$$.

\begin{tabular}{|c|c|c|c|c|c|c|c|c|c|}
\hline PV & WIND & Battery & Grid & NPC & $\mathrm{COE}$ & operating cost & $\begin{array}{l}\text { Cost/Initial } \\
\text { capital (\$) }\end{array}$ & $\begin{array}{c}\text { System/Ren } \\
\text { Frac (\%) }\end{array}$ & $\begin{array}{c}\text { emmsion } \\
\mathrm{kg} / \mathrm{yr}\end{array}$ \\
\hline & & & on & 10147.640 & 0.048 & 720.000 & 0 & 0 & 9480 \\
\hline 0.056 & & & on & 10162.170 & 0.048 & 716.220 & 67.801 & 0.531 & 9430 \\
\hline 0.066 & & 1 & on & 10441.900 & 0.049 & 713.131 & 391.066 & 0.735 & 9410 \\
\hline \multirow{3}{*}{0.382} & 1 & & on & 12380.080 & 0.059 & 765.316 & 1593.750 & 2.488 & 9244 \\
\hline & 1 & 1 & on & 12649.170 & 0.060 & 728.906 & 2376.004 & 7.362 & 8782 \\
\hline & 1 & 1 & on & 12656.330 & 0.060 & 762.302 & 1912.500 & 2.681 & 9226 \\
\hline 0.723 & 1 & & on & 12849.960 & 0.061 & 759.264 & 2148.927 & 3.409 & 9157 \\
\hline
\end{tabular}

The critical factors (for example, the size of the PV, converter and the number of wind turbines and batteries) that are required to provide the electricity demand are distinct from the environment parameters of a selected area at Riyadh, and they could have a profound effect on the cost of the system as well. It is primarily due to the fluctuation of the city's primary parameters, such as solar radiation and wind speed, to determine the solar panel size and the amount of solar radiation power turbines used and the optimum application of the wind speed. Higher irradiation or wind speeds may result in the load needed without using grid electricity and reduce the electricity used by the grid.

\section{Conclusion}

As a conclusion, several changes in electricity prices in the Kingdom has been done and recently in 2018 was the last change in the electricity tariff in the Kingdom, especially for the residential sector which aims to make several reforms to the electricity sector in the Kingdom, implicitly in the goals of Vision 2030 for the Kingdom where the electricity tariff for the residential sector became for the first and second tiers (1 - 6000-kilowatt hours (kWh) and (6001-kilowatt-hours and higher) at a value of $\$ 0.048 /$ kilowatt-hour and $\$ 0.08 / \mathrm{kWh}$ respectively, which ultimately aims to link electricity prices to global energy prices. The cost of electricity today in the Kingdom is considered a non-incentive for the acquisition of a renewable energy system, as the electricity tariff from the grid in Saudi Arabia is cheaper than its cost than the renewable energy systems. But in the event that electricity prices are raised in the Kingdom and it is expected that electricity prices in the Kingdom will rise to become similar to the prices of commercial categories in the next 10 years $\$ 0.08 / \mathrm{kWh}$, it is possible that the renewable energy system is economical and the cost of electricity is cheaper than acquiring it from the grid to meet the needs of the residential consumer in the Kingdom. where it shows that PV-Grid system can provide electricity with a price of 0.075 $\$ / \mathrm{kWh}$ cheaper than electricity from the grid of $0.08 \$$ per each $\mathrm{kWh}$. 


\section{Data Availability}

1) The data that support the findings of this study are openly available in Global Atlas at https://globalsolaratlas.info/map, reference number [10].

2) The data that support the findings of this study are available from [K.A.CARE. Restrictions apply to the availability of these data, which were used under license for this study. Data are available from the authors upon reasonable request and with the permission of K.A.CARE [11].

3) The data that support the findings of this study are openly available in EIA at https://www.eia.gov/tools/faqs/faq.php?id=74\&t=11, reference number [16].

\section{Conflicts of Interest}

The authors declare no conflicts of interest regarding the publication of this paper.

\section{References}

[1] IEA International Energy Agency. The World Energy. https://www.iea.org

[2] Alyousef, Y. and Abu-Ebid, M. (2012) Energy Efficiency Initiatives for Saudi Arabia on Supply and Demand Sides. In: Morvaj, Z., Ed., Energy Efficiency: A Bridge to Low Carbon Economy, IntechOpen, London, 297-308. https://doi.org/10.5772/38660

[3] OWD. Our World Data. https://ourworldindata.org

[4] Khan, K.S., Ullah, Z., Khan, B., Sami, I., Ali, S.M. and Mehmood, C.A. (2017) Assessment of Hybrid Off-Grid Wind Photovoltaic System: A Case Study of University Campus. International Conference on Energy Conservation and Efficiency, Lahore, 22-23 November 2017, 16-21. https://doi.org/10.1109/ECE.2017.8248822

[5] Hutapea, S.F. and Purwadi, A. (2017) Design of Hybrid PV-Generator-Battery System for Two Kind of Loads at Aha Village, Morotai Island, North Maluku. 2017 Control, Electronics, Renewable Energy and Communications Conference, Yogyakarta, 26-28 September 2017, 127-131. https://doi.org/10.1109/ICCEREC.2017.8226672

[6] Zebraoui, O. and Bouzi, M. (2017) Sizing and Optimization of a Fully Autonomous Hybrid PV-Wind Power System. International Conference on Electrical Sciences and Technologies in Maghreb (CISTEM), Marrakech, 26-28 October 2016. https://doi.org/10.1109/CISTEM.2016.8066799

[7] Farahi, S. and Fazelpour, F. (2019) Techno-Economic Assessment of Employing Hybrid Power System for Residential, Public, and Commercial Buildings in Different Climatic Conditions of Iran. Environmental Progress \& Sustainable Energy, 38, 614-623. https://doi.org/10.1002/ep.12961

[8] Haidar, Z.A. and Al-Shaalan, A.M. (2018) Reliability Evaluation of Renewable Energy Share in Power Systems. Journal of Power and Energy Engineering, 6, 40-47. https://doi.org/10.4236/jpee.2018.69006

[9] Imam, A.A., Al-Turki, Y.A. and Sreerama Kumar, R. (2020) Techno-Economic Feasibility Assessment of Grid-Connected PV Systems for Residential Buildings in Saudi Arabia-A Case Study. Sustainability, 12, 262. https://doi.org/10.3390/su12010262

[10] Atlas, G. Solar Satellite Data. https://globalsolaratlas.info/map

[11] King Abdullah City for Atomic and Renewable Energy. Solar and Wind Resource Data. https://www.energy.gov.sa/en/projects/Pages/atlas.aspx 
[12] Diaf, S., Diaf, D., Belhamel, M., Haddadi, M. and Louche, A. (2007) A Methodology for Optimal Sizing of Autonomous Hybrid PV/Wind System. Energy Policy, 35, 5708-5718. https://doi.org/10.1016/j.enpol.2007.06.020

[13] Ghasemi, A., Asrari, A., Zarif, M. and Abdelwahed, S. (2013) Techno-Economic Analysis of Stand-Alone Hybrid Photovoltaic-Diesel-Battery Systems for Rural Electrification in Eastern Part of Iran: A Step toward Sustainable Rural Development. Renewable and Sustainable Energy Reviews, 28, 456-462.

https://doi.org/10.1016/j.rser.2013.08.011

[14] Palit, D. and Chaurey, A. (2011) Off-Grid Rural Electrification Experiences from South Asia: Status and Best Practices. Energy for Sustainable Development, 15, 266 276. https://doi.org/10.1016/j.esd.2011.07.004

[15] Shahzad, M.K., Zahid, A., Rashid, T., Rehan, M.A., Ali, M. and Ahmad, M. (2017) Techno-Economic Feasibility Analysis of a Solar-Biomass Off Grid System for the Electrification of Remote Rural Areas in Pakistan Using HOMER Software. Renewable Energy, 106, 264-273. https://doi.org/10.1016/j.renene.2017.01.033

[16] Bank, T.W. Co2 Emission.

https://databank.worldbank.org/id/4c817707?Report Name=CO2-emission11 